\section{パル；南ドイツにおける中心地の頻度分布：その後の研 究}

Parr, J.B. (1980) ; Frequency Distributions of Central Places in Southern Germany : a Further Analysis, Economic Geography, 56, 141 154.

Parr の中心地理論の分野への貢献または問題の提起に ついて大きく 3 つに集約できると考えられる。その 1 は Beckmann(1958)が発表した中心地理論の都市階層と都市 の順位規模分布法則との統合モデルについての批判 (1969)，その 2 は Dacey（1966）が Christaller の中心地 理論と都市の順位規模法則とが相容れないと発表したこと に対しての批判 (1975)，その 3 は自ら提案して来たいくつ かの都市の一般階層モデルの研究である。

今回の論文はその 3 の研究の続きとしてクリスタラーの 中心地理論のうち，主に都市 (中心地) の階層的頻度分布 とそれと関連して都市配置の原理とも言われている $K$ の 值についての研究である。

Parr は中心地システムに打ける社会・経済条件と技術 の革新, 消費者の嗜好の変化, 後背地人口の減少, ある機能 の成立閾の変化が時系列的に働いた結果もたらされた中心 地システムの構造的変化 (Structural Change)を考慮する。 また，その変化と関連してChristaller とは異なって $K$ の 值を常数ではなく, パラメタとし， $L$-system ごと,レベル ごとに変化させて説明する。それは Lösch-Känzig のモデ ルと同様に $K=3$ (供給原理), $K=4$ (交通原理), $K=7$ (行 政原理)の他に, $K_{i}$ の值の変化に意味を与える。すなわち, $K_{i}$ が大きいことは高次の成立閾機能特性を, それが小さい ことは低次の成立閾機能特性を表わす。
Parr は構造的変化について次の 3 つの場合を考え, それ に合わせて $K_{i}$ 值の変化を説明する。

I 型変化; 新しい中間レベルの形成

II 型変化; あるレベルにおける中心地の数の変化

III 型変化; あるレベルの中心地の消隇

I 型の変化は消費者の需要の変化を引きおこす消費者の嗜 好の変化により, II 型変化は後背地の農村人口の減少によ ク, III 型変化はレベル 8 への交通網とある機能の成立閾の 急激な変化により生じると考えている。

ぬた，Parr はChristallerの詋りとそのモデルの制約を 論じ，フレクシブルな一般階層モデル（General Hierarchical Model）を提案する。それは,

$$
f_{m}=\prod_{i=m}^{N-1} K_{i}-\prod_{i=m+1}^{N-1} K_{i}
$$

として定義される。ここで, $f_{m}$ は $m$ レベルの中心地の出現 頻度, $N$ は $L$-systemの中のレベルの数で $8 K_{i}$ は $L-$ system ごと・レベルごとの $K$ の值である。たとえば, Nürnberg のL-system の場合，観測された階層的出現頻 度は $1,2,10,23,60,105 \cdots \cdots$ の系列, モデルによって計算 された理論的な出現頻度は $1,2,9,24,72,108 \cdots \cdots$ の系列 を見せ, Christallerのモデルと比べてはるかに実際に近つ くことができたと言える。

しかし，この論文の問題点は, 一般階層モデルの適用の前 に, $\left\{K_{i}\right\}$ の要素の值の決め与で, 以前として現実的には 経験法則に依存せざるを得なくなることである。

（朱京植）

\title{
1980 年度秋季学術大会記事・発表要旨
}

1980 年度秋季学術大会は, 福島地理学会と共催で 11 月 1 日・2 日・3 日の 3 日間にわたって福島県双葉郡富岡町夜 ノ森六芳苑を主会場として開催された。

11 月 1 日・2 日の両日は研究発表が行なわれ, 延べ 25 の 発表があり，活発な討議が交わされた。11月 1 日の夜には 同じく六芳苑を会場として，懇親会が行なわれ，約 50 名の 参加者が親交を深め合った。

11 月 3 日には「福島県浜通り中部・北部の地域開発」を テーマとして，巡検が行なわれたが，その詳細については 別の報告にゆずりたい。

今回の大会は大会々場が交通の便に恵まれないことむ あって, やや参加者が少なかったが，研究発表・巡検共に 充実した内容であったといえる。大会の運営にあたられた， 福島工業高等専門学校の原田栄会員をはじめとする福島地
理学会の方々に深く感謝申し上げる。

（文責 阿部 隆）

研究発表座長氏名

\begin{tabular}{|c|c|c|c|c|}
\hline 発表番号 & 座長氏名 & 発表番号 & \multicolumn{2}{|c|}{ 座長氏名 } \\
\hline $01 \sim 03$ & 米地 文夫 & 16 & 田辺 & 健一 \\
\hline $04 \sim 06$ & 板倉 勝高 & $17 \sim 18$ & 原田 & 栄 \\
\hline $07 \sim 08$ & 細川 幸也 & 19 & 杉浦 & 直 \\
\hline $09 \sim 11$ & 大沢貞一郎 & 20 & 境田 & 清隆 \\
\hline $12 \sim 13$ & 瀬川 秀良 & $21 \sim 22$ & 中村 & 嘉男 \\
\hline 14 & 米地 文夫 & 23 & 金安 & 岩男 \\
\hline 15 & 元木 靖 & $24 \sim 25$ & 阿部 & 隆 \\
\hline
\end{tabular}




\section{1. 判別分析による風成砂，海成砂の区分}

$$
\text { 長谷川 }
$$

海浜砂や砂丘砂などの粒度組成をもとに，沖積平野の堆 積環境区分を試みる方法としては，正規確率紙上での積算 曲線のТype 分けや, $\bar{x}, \sigma \phi, \alpha \phi, \beta \phi$ などの統計值による, 散布図上での区分が一般的である。しかし, 後者の例では, 散布図上で重複部分が生じ，明確に区分できない場合も多 い。この理由は, 粒度階ごとの重量\%を, 統計值に変換し, その值を用いて図上区分を行なら際の，変換の方法が適切 でないこと，あるいは，本来，環境区分は，統計值の相関 など，2変数のみの組み合せでは表現しえないことなどが 考えられる。これらの点を解決する一方法として, 総ての 粒度階に打汸る重量\%DATAの相互関連を, 同時的に数 量化する手法が考光られる。

石狩平野に打いて採取した，海浜砂，砂丘砂，浜堤砂（計 66 試料) について, これら 3 グループ間と, 2 グループの 組み合せで, $1 / 4 \phi$ 粒度間隔ごとの重量 \%と, 比較の意味 で，積率法による 4 統計值を用い，それぞれ判別分析を行 ない, その有効性を検証した。

重量\%をもとにした判別分析の結果では，海浜砂と砂丘 砂の組み合せで, 海浜砂が海浜砂と判別される割合は約 $92 \%$, 砂丘砂が砂丘砂と判別される割合も約 $92 \%$ であり, 海浜砂と浜堤砂，砂丘砂と浜堤砂の組み合せでも，90 $100 \%$ の割合で, 本来の所属グループへ判別された。また, 3 グループ間での分析でも, 同様に高い割合で本来の所属 グループヘ判別された。

この結果, 本地域で, 地形判読や露頭観察では, 採取時 に所属グループが決定できない試料があった場合, 判別分 析によって, 本来の所属グループに正しく推定する確率を 求めると, 2 グループ, 3 グループ間のいずれにおいても, $90 \%$ 以上の確率になる。このことから, 従来の散布図上で の区分に比べ，より明確に所属グループの所属グループに 正しく推定する確率を求めると, 2 グループ, 3 グループ間 のいずれに拈いても，90\%以上の確率になる。このことか ら, 従来の散布図上での区分に比べ, より明確に所属グルー プの推定が可能になる。

\section{2. 仙台付近の最近の地盤変動状況と微地形・表層地質 との関係にっいて}

$$
\text { 菅原啓 }
$$

仙台付近の地盤・地質は長町〜利府構造線の西方台地域 で鮮新統基盤岩類の堅硬な地盤をなすのに対し，東方平野 域では基盤岩類が深く, 厚い第四系が堆積し, 特に沖積層 基底扣よび表層には極軟弱な粘性土層が堆積し, 平野上の 自然堤防帯, 後背湿地群, 旧改道群等の複雑な微地形とも 相まって沖積層の構成もかなり複雑である。平野部の軟弱
地盤を形成する沖積粘性土層は多賀城付近から仙台長町方 面へかけて何か所かに厚い島状の堆積域を形成して拈り, 近年の平野域の地盤沈下現象に対する自然的素地を作って いるともいえる。仙台付近の最近の地盤変動状況にはこの ような自然的環境を反映するかの如くかなり明瞭な地域性 が発現している。最近 5 ケ年間の水準測量成果によれば, 西方台地域は変動量は概して小さくむしろ隆起気味なのに 対し, 東方平野域は活ぶ全域が累積 $10 \mathrm{~mm}$ 以上の収縮を 示す。特に苦竹一帯・高砂〜多賀城・蒲町〜荒井・長町 〜郡山・荒浜〜種次等の地域で明瞭な地盤収縮域が出現 し, これまでに苦竹扇町地区で最大 $115 \mathrm{~mm} / 5$ 年の累積収 縮量を観測している。これらの地域はいずれも厚い沖積粘 性土分布域に当り，平野上の後背湿地・旧河道部之も対応 することが多い。逆に自然堤防帯・台地部等では軽微な变 動にとぶまって招り, 地盤変動と表層地質・微地形等とが 密接に係り合っているのが知られる。な打平野部の地盤収 縮量の約 $1 / 2$ 相当量は 1978 年宮城県沖地震時の沖積軟弱 地盤の地震性圧密によるものであるが，以後 1 年以上を経 てな打収縮傾向は継続して扣り，この地盤収縮の背景には 平野域の急速な開発に伴なら地盤圧密の人為的な加速をも 伺うことがでさる。尚，この地震時の地盤変動には基盤岩 類も含めて長町一利府構造線の東西で明瞭な相反する傾向 が出現しており,この構造線がある程度活動した可能性も あることをも指摘しておく。

\section{3. 北上山地東部に分布する繩文前期火山灰について 菊池 強一・桧垣 大助・吉永秀一郎}

北上山地中, 北部には, 奥羽山脈起源の火山灰層が分布 する。ところが，三陸沿岸を含む山地の東部には，分布か らこれらとは給源を異にし，乙か子広域に分布する火山灰 が認められる。本火山灰は, 岩泉町安㒸付近で最も厚く, しかも岩相の特幑がよく現われていることから，これを安 家火山灰と呼ぶ。これまで沢の口火山灰・岩泉火山灰など と呼ばれたものは，これに相当する。

分布恃, 五葉山一遠野市石上山一区界一岩洞一葛巻田部 一大野村より東方に限られ，岩泉から安家にかけては，最 大層厚 $1 \mathrm{~m}$ を越す所もあるが, 西及び南に向から汪ど, 層 厚を減じ，北上川上流低地带には認められない。

安家茂井遺跡に拈いては，本火山灰を挾んで，上下に繩 文前期初頭の時期を異にする二枚の文化層が発達する。そ して本火山灰上位及び直下の埋没土C-14 年代が，それぞ

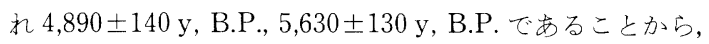

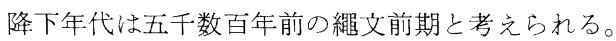

給源に関しては，現在のところ不明であるが，岩手山， 十和田湖，八甲田山，恐山付近には，該当する様な火山灰 は夕つけていない。

安家火山灰は, 一般に山頂・山麓・支谷堆積の各緩斜面 
を構成する角礫層を覆っているが，崖錐や小扇状地では, それらの構成層上半部に㣣在することが多い。段丘形成期 等から考えて, 約 1 万数千年前から安家火山灰降下までの 方が，安家火山灰降下以降現在までより，同一時間あたり の岩屑供給量が，相対的に多かったと予想される。

いっぽう, 山頂緩斜面にみられる Involution は, 安家火 山灰降下以前すなわち約五千数百年前以前に形成が終了し ている。

\section{4. 横手盆地の転作に伴うリンドウ栽培}

菊 池 勝 俊

日本における切花リンドウ生産は，長野県および岩手県 を中心として拈り，福島県や栃木県などに扣いても生産量 が増加している。

一方, 秋田県でも, 近年, 転作に伴い, 横手盆地に括い て栽培面積が増加している。

本調査では，この栽培の実態を明らかにすることを目的 としている。

方法としては, 県農産園芸課, 県経済連, 農業改良普及 所, 秋田生花市場などの統計資料に現地調查および聴き取 りを加え補充した。

まとめとして次の諸点に要約される。

1. 横手盆地のリンドウ栽培は, ’ 71 年に始まり, 県特産 花卉育成事業と水田利用再編対策との関係で, 栽培面積を 增加させた。

2. 地区別導入の経緯では，雄勝地区へは花卉先駆者を 通して'76 年以降個別に, 仙北地区へは地区花卉連の活動 を通して’77 年より集団栽培, 共選共販の方法で行われた。

3. 栽培技術の伝達者は 5 人を数光, 自ら系統選抜に取 り組むと共に，花卉栽培の経験のない農民の先頭に立って 指導し，行政の浸透を側面から支えた。

4. 栽培地区は, 千畑村千屋, 大曲市, 仙南村金沢, 仙 北町横堀など平場を中心として㧍り，山間部としては，大 森町八沢木があげられる。

5. 仙北地区は, 一戸あたりの水田面積が大きく, 共販 体制もあって, 今後面積の拡大が見込まれる。一方, 雄勝, 平鹿地区は, 流動的である。

6. 仙北地区では, 早生種の秋田市市場および北海道・ 東京市場への出荷が行われる。等級任低いが，比較的高い 収益をあげている。雄勝地区では, 晚生種の東京市場への 出荷が行われる。上物率は高いが, 収益性は低い。

\section{5. 横手盆地における漬物加工産業}

斎藤 実則・佐々木順誠

本発表の目的は横手盆地にお污る漬物の行なわれている 実態と漬物の種類及び生産の推移と地域的特色から把握
し, 次に漬物加工産業の実態を分布及び, 経営形態, 製品, 創業年次, 創業の経緯等, 経営の特色から明確にすること である。

調査方法は前者については横手盆地内の 4 高校生の家庭 への約 1,000 枚のアンケート調査をした。後者については 漬物工場の企業化の実態と特色を各工場への個別調査の聞 さ取り調査で資料収集をした。

あとめとして次の諸点に要約される。

1. 横手盆地内の一般家庭で作る漬物は減少傾向にあ り,特に都市部に顕著である。また漬物の種類は平均 5.9 種 類で都市部の大曲市湯沢市が少なく，仙北郡内が多い。

2. 漬物の材料は三つに分類される。野菜（なす，きゅ うり, 大根など), 山菜 (わらび, きのこなど), 果実 (梅, 杮）となる。

3. 家庭で作らなくなった理由は食生活の変化，生活の 合理化，核家族化，住宅事情，加工の技術の問題などがあ げられる。

4. 地元に漬物工場の企業化がみられる。横手盆地内に 33 工場で大曲市, 仙北部に 18 工場, 全工場に占める割合は $54.5 \%$ である。市町村別では湯沢市 6 工場, 田沢湖町 5 工 場である。

5. 工場の立地について三形態がみられる。山麓と平地 の遷移点に山菜加工立地 (田沢湖町), 市, 町の地場消費地 （湯沢市, 大曲市) 平地農村の原料産地（平鹿町，雄物川 町, 中仙町) の三つである。

6. 創業年次は 1970 年以降が 21 工場で全工場の $63.6 \%$ で米の生産調整に伴う転作農産物の産地加工の形態が多 い。平鹿町の浅舞漬物研究会, 集落農場化の雄物川町の大 西根グループ, 生活改善からスタートした山内特産加工組 合他が好例である。

7. 企業化の形態は協業, 個人経営が 24 工場, 全工場の $72.8 \%$ である。労働力は女子型余剩労働力中心で従業員 10 人以下の小規模経営である。

8. 製品の中心はいぶりたくあん加工中心で次いでみそ 漬加工である。いぶりたくあん加工は山村部で，野菜のみ そ漬加工は平坦部に多い。

9. 原料の供給及び製品の出荷圏は地元県内指向であ る。一部中央市場へ進出している例として湯沢市の酒かす 漬，平鹿町のみそ漬がある。

\section{6. 農業集落単位にみた仙台市周辺の農業}

青 柳 光太郎

本報告は, 仙台市周辺の 1960 年から 75 年までの農業・ 農家の動向を, 農業生産活動・農村地域社会の最小の基礎 地域と考えられる農業集落単位でみようとするものであ る。

対象地域は, 2 万 5 千分の 1 地形図, 根白石, 塩釜, 仙台 
東南, 仙台東北, 仙台西南, 仙台西北, 仙台空港, 岩沼の 8 図幅の地域である。資料は, 1970 年・75 年の農業集落 カードを用いた。前に農業集落単位に分析すると述べたが, 図化表現上，基準 mesh に組み替樂を行い，分析単位とし た。

総農家数の推移をみると, 60 年から 75 年にかけて減少 傾向がみられるが，特に70 年以降が著しい。地域的な傾向 をみると, 仙台市街地周辺部と塩釜・七ケ浜の丘陵部に顕 著な減少がみられ，70 年以降それらに，名取・岩沼の中心 部が加わってきている。

耕地面積の推移をみると, 60 年から 70 年むでの増加地 域は, 西部の丘陵部と七北田川・名取川の河口部である。 減少が著しいのは, 都市的土地利用への転化が激しい, 仙 台市街地周辺部之岩沼・名取の中心部である。70 年から 75 年までの変化をみると, 全般的に減少基調に転じ, 60 年か ら 70 年末での減少地域は, その比率を一層減少させている ことがわかる。

修正ウィーバー法を用いて，作物別收穫面積の推移をみ ると, 60 年から 75 年にかけて, 組み合せ型の単純化がみら れ, 稲のみを指向していることがわかる。麦類, 雑穀, 豆 類は丘陵部に多くみられたが，まず70年時点で豆類が消 え, 75 年で麦類・雑穀が消方る傾向がみられる。また, 野 菜類は七北田川・名取川流域に多くみられたが，75年で は，名取川流域と塩釜・七ケ浜になってきている。土地利 用率と耕地面積の増減とを併せ考えてみると, 仙台市の近 郊農業地帯法名取川流域の自然堤防・微高地に限定される と考えてよいと思われる。しかし，組み合せ型をみると， 稲の面積が, 野菜類より多いところが数多くみられ, 水稲 作への依存度は高い。

\section{7. 庄内平野と新庄盆地の気温分布の不連続について} 田島康之

庄内平野と新庄盆地周辺地域では, 早朝, 相対的に庄内 平野側が高温, 新庄盆地側が低温で, 分布図の上からは, 平野と盈地の境界にあたる出羽丘陵に等温線の密集する気 温の不連続的分布がしばしばみられる。そこでこの不連続 的分布の季節的・時間的特性を調べ，それぞれの地域の気 温分布の微細な構造を考察した。資料は, 農業気象観測所 の 09 時の気温を海面補正せず，そのまま使用した。

その結果, 平野側の酒田の09 時の気温が, 盆地側の新庄 より $5^{\circ} \mathrm{C}$ 以上高い典型的な不連続的分布は $10 \cdot 11$ 月にそ れぞれ $28.24 \%$ の頻度で発生し, 次いで 4・5 月に $19.17 \%$ と頻発し, 夏季及び $2 \cdot 3$ 月には, 発生数が少ない。この不 連続的分布は, 夜間に拈ける平野部のゆるやかな気温の降 下と, 盈地部の気温の急下降といら日変化パターンの相異 に起因するといえる。

このような不連続的分布の出現する総観的な条件につい
てみると, 移動性高気圧の影響下で, 晴天, 新庄において は, $1 \mathrm{~m} / \mathrm{s}$ 程度の弱風時で, 酒田では南系, 新庄では北系の 地上風系の時に顕著に出現する。

これらの結果を総合すると, 両地域の気温の不連続的分 布は, 新庄盆地では放射冷却の影響で冷気が盆地底にたま り接地逆転を抗こし, 冷気湖が形成されるのに対して, 庄 内平野では海洋の影響をらけて, 夜間に扣ける冷却がゆる やかであるために，両地域間で著しい気温の差が生ずるた めと考觉られる。

このよらな不連続的分布のみられる時には，平野内に沶 いても特徵ある気温分布がみられ，狩川・藤島などの地点 では周井より $1.5^{\circ} \mathrm{C}$ 程度低温になる傾向が認められる。こ れは, 最上川の谷から盈地の冷気が平野部に流出し, この 影響によるものではないかと考えられるが，今後の検討を 要する問題である。

\section{8. ビル街を東西に走る道路の両側における気温の垂直 分布}

境田 清隆・設楽寛

都市中心部ではビルの高層化が進さに従って日陰面積が 増大し, 受熱面は地表面から建物の壁面, あるいは屋上面 に移行しつつある。一般に都市はその周辺地域に比べ相対 的に高温を示すことが知られているが，日中の都市では， 受熱面の高層への移行によって, 人為的な気温の逆転現象 が生じていると考えられる。そのような観点から，仙台に おいて最も高層化の著しい地区の 1 つである青葉通東三番 丁に颃いて気温の垂直分布を調査した。調査方法は，東西 に走る青葉通を狭んで立つ南北両側のビルの上部から, サーミスター温度計を約 $5 \mathrm{~m}$ 間隔で 5 個ずつ懸垂し, 名層 の気温変化を自記紙に記録させた。観測は，1）1979年 11 月 $18 \sim 24$ 日，2） 1980 年 4 月 21 26日，3）1980年 9 月 23〜26日，の3つの期間にわたっておこなった。

その結果, 都心に打る気温の逆転は夜間や早朝よりも むしろ晴天の日中に現われていることがわかった。また日 中の気温の逆転は道路の南側 (日陰側) では季節を問わず 現われるが，北側 (日向側) の気温の垂直分布型は季節に よって大きく異なっている。すなわち 11 月には強い逆転 型，4月には反対に不安定型が現われ，9月はそれらの中間 型を呈する。

このような季節的差異は, 調査地域付近の建物模型 (500 分の 1)による簡単な日照実験の結果と矛盾しない。すなわ ち太陽の南中高度が比較的大きい 4 月下旬では, 道路の北 側の受熱量の減少はほとんど認められず路面が熱せられて 不安定型を示すが, 南中高度の小さな 11 月下旬には道路北 端の受熱量は春秋分時の 3 分の 1 に減少し, 道路面は受熱 面たりえず, 南側同様著しい逆転型を呈すると考えられる。

今後さらに調査を進め, 街路樹による日陰の影響を含め, 
ビル街を貫く道路上の微気象の実態を明らかにしていさた いと考える。

\section{9. 東北地方における果実加工の奏態}

$$
\text { 一干しがきの場合—石川雄造 }
$$

\section{目的}

東北地方では 1883 年青森県の藤田ぶどう園ではじめて のぶどら酒，鹿角市のなるめろ缶詰をはじめ，りんご，も も，打らとら，西洋なし等の果実加工が行なわれてきた。 かきの場合は甘がきが生食用，渋がきはアルコール脱沾と 干しがき（ころがき，あん汸がき，串がき）として加工さ れているのが現状である。

今回は, 農家が手がけている干しがき加工について，原 料がきの需給関係, 干しがきの生産量, その出荷状況を通 して，主産地の実態を明らかにしたい。

方 法

農林水産省園芸統計課の青果物出荷統計により各県, 各 市町村別の収穫量, 出荷率, 加工率を算出した。調查地と して福島県梁川町, 宮城県白石市, 丸森町, 山形県上山市 を選び，前記の 3 地区の各種統計資料，文献を使用したほ か, 現地調査、アンケートを実施した。

\section{結 果}

かき加工率の高いのは福島県の梁川, 保原, 桑析, 霊山, 月館町, 福島市, 宮城県の白石, 角田市, 丸森, 蔵王町, 山形県の上山，村山，山形市である。これら加工地では, 今までの放任園, 散在樹からの原料がき確保から, 品質の 良い子のを得るため樹園地造成と苗木育成を行っている。 次に，干しがき製造の大半は，原料がきの生産農家が個々 に生産してきたが, 青果商が原料, 乾燥場を確保して生産 する傾向にある。製造過程の変化として，真空自動はく皮 機を使用して傭人費をカバーし，乾燥方法では，天日乾燥 に火力乾燥を併用し出荷時期を調整している。干し場は, 軒下から宅地内へ木製や鉄製を増設し大量生産に対応して きた。出荷先は, 京浜・阪神地区には福島産, 北海市場に は宮城産が多いが，山形産は両地区へ均分して出荷されて いる。

\section{0. 北上山地の先進林業地域}

\section{四津 隆一}

目的: 北上山地は青森, 岩手, 宮城の三県にまたがって いるのに，行政区に支配されて県毎にあつかわれ，特に岩 手県の北上山地だけが多くあつかわれてきた。また北上山 地は現在でも本邦最大の製炭地域であり，薪炭林が多く， その経済性が低い点で後進林業地域の一つとみなせる。し かし, 北上山地の林業にも地域差が認められるので, 本発
表では北上山地の林業を概観したらえで，先進林業地域を とりあげ，その実態を明らかにしようと試みた。

方法：林野庁执よび青森県, 岩手県, 宮城県の各県で得 た資料により，北上山地の林業を概観し，さらに先進林業 地域とみなされる南部地域のらち，扣もに岩手県気仙郡住 田町の林業を調查した。

要約: 北上山地の山林は林業の対象以外にも山地牧畜, 山地農業, 山岳観光の対象地域となっていることはいうま でもない。北上山地ではやや北寄りの岩手県閉伊郡，九戸 郡は現在も著名な製炭地域であり, 天然更新に依存す而薪 炭林経営は粗放的である。

もっとも，薪炭需要の減少が用材林林業への転換をもた らすようになったが，人工林化は北縁，西緣执よび南部の 里山で進み，なかでも岩手県南部から宮城県にかけて著し い。これは林業資本の大小にもよるが，その活か山村に拉 ける自治体の意欲的な林政にもよると考えられる。

住田町の林業は後者の例とみなされ，林野のうち広く占 める町有林の人工林化が進められている。人工林化の一方 策として個人分収林制度を適用して，長期林業を実施する 一方，椎茸栽培とそのほだ木育林の短伐期林業を併用し， さらにイチゴ，葉たばこ栽培を混合させた複合型土地利用 は，先進林業地域の一類型と評価できる。

\section{1. 雄物川蛇行帯における農業水利}

大坂 昭治・斉藤 実則

I. 目 的

本地域は雄物川中流に位置し, 古来, 洪水の常襲地帯て ある。秋田県仙北郡西仙北町強首地区之協和町小種地区に おける, 明治以降の農業水利の実態とその特色について報 告する。

II. 万 法

「雄物川狹窄部の地形・洪水・土地利用・扣よび集落 (1961 横浜市立大紀要 籠瀬良明),「藩政期にお污る河川 改修工事一一強首地区を例として一」」(1962 秋大地理 工藤吉次郎)，「秋田県雄物川の河跡湖之旧流路について」 (1933 地学雑誌 岩佐德三郎) などの参考文献と現地調査 (町役場・土地改良区での資料集収, 聴き取り，写真撮影） によった。

\section{III. 結 果}

本地域に抢汁る農業水利は，長い間ため池や河跡湖に依 存し, 雄物川からの揚水が開始されたのは昭和初期であっ た。広い面積を占める雄物川の後背湿地では, 泥炭土が多 く, 排水覀かった。水害と旱害のくり返しで，生産性は 低く, そのため早くから北洋や南水洋への出稼ざが行われ て来た。

戦後の米増産時代を迎えて本格的な土地改良事業を施工 し, 特に昭和 28 年から着工した県営強首用水事業は用水量 
の安定化と生産力の向上につながり, 農家の余劋労働力の 一部は誘致工場などにも吸収されるようになった。 明治以降の土地改良事業史は次のように区分される。 第 1 期（明治・大正）ため池依存の時代 第 2 期 (昭和初期 終戦) 初期の土地改良事業 第 3 期（昭和 20 30 年代）米増産時代 本格的土地改良事業が行われた。

第 4 期（昭和 45 年以降）米余剩時代（水田十畑作）

\section{2. 淡路島三原平野の地形発達史}

\section{高 橋学}

従来, 臨海平野の地形分類に用いられてきた術語は, 必 ずしも同レベルで比較できるものではなかった。そこで「地 形形成に要した時間」を指標として, 術語を構造化し整理 を抗こなった。そして，それを用いて，編まれた地形発達 史に立脚した地形分類を試みた。選ばれたフィールドは, 我国の地形要素がコンパクトにまとまっていると思われ る, 淡路島三原平野である。

調査方法：(1) 空中写真を用いて, 形態的特徵から成因分 類を执こない，認識できる地形の「最小単位」を設定する。 （2）設定された「最小単位」を形成に要した時間の点から, (1) $10^{5}$ 年およびそれ以上, (2) $10^{4}$ 年, (3) $10^{3}$ 年, (4) $10^{2}$ 年およびそれ以下のうち,どのオーダーに当るか検討する。 （3）オーダーに応じた方法で, その構成物および構造を調へ る。その際，可能な限り絶対年代の決定を抗こなう。（4 各オーダーごとに古地理の復原をおこなら。(5) オーダー を考慮しながら地形発達史を編む。(6) 編まれた地形発達 史をもとに地形分類を抏こなら。その際, 認識された「最 小単位」のオーダーを示すよらに構造化した凡例を用いる。

以上の結果，山地，丘陵や人工地形などをのぞき，三原 平野は 3 地形面 $\left(10^{4}\right.$ 年オーダー), 7 地形域 $\left(10^{3}\right.$ 年才一 ダー), 16 微地形単位（10 年オーダー）に分類できた。

特に $10^{4}$ 年オーダーでは, 基盤をなす大阪層群と段丘・ 扇状地などの関係について明らかにした。10 年オーダー では，いわゆる繩文海進抢よびその後の海退に対して，流 域ごとに反応が異なっていた点に注目し，その原因につい て考察した。

なお，人間の開発と地形形成について，考古学の発掘成 果をふまえて検討を抗こなった $10^{2}$ 年オーダーについて は，時間の都合上，別の機会に報告したい。

\section{3. 北海道, 沙流川における河岸段丘堆積物の分析}

\section{柳田誠・太田 尚寛・水野 秀明}

北海道の沙流川に発達する河岸段丘を火山灰によって対 比し，その堆積物の粒径分析を行い，最終氷期以降におけ る河岸段丘の形成環境について考察を行った。沙流川の支
流の額平川の源流部には最終水期に山岳水河が存在して扣 り，沙流川は現在の海岸付近までほぽ周水河地域となって いたと考えられる。調查地域内の主な火山灰はSpfa 1（約 3.3 万年前) ・ En-a (約 1.5 万年前) ・ Ta-d (約 6,000 年 前) である。段丘面はSpfa 1 以上に被われる Ms 面, En-a 以上に被われる MwI 面, Ta-d 以上に被われる MwII 面, 腐植質火山灰に被われる MK 面に区分される。河口から約 $30 \mathrm{~km}$ 付近では Ms 面・MwI 面・MwII 面は20〜40 m の 比高を持つ侵食段丘群であるが，40〜 $50 \mathrm{~km}$ 付近で $3 つ の$ 段丘面は収れんする。50〜60 $\mathrm{m}$ 付近では段丘堆積物の厚さ は20〜40 m となり堆積段丘となる。

以上のような段丘面の堆積物と現河床に打汀る $1 \mathrm{~m}^{2}$ の 中で最大礫から 50 個の長径を計測した。ここでは野上ほか （1979）が指摘したように最大礫から 5 番目の礫の長径を その地点での代表粒径とした。粒径と河口からの距離との 関係は沙流川下流々額平川について, Ms 面： $\mathrm{y}=26.37$ ・ $2^{-0.0150 x}$, MwI 面: $\mathrm{y}=37.27 \cdot 2^{-0.0322 x}$, MwII 面: $\mathrm{y}=$ $10.35 \cdot 2^{0.0243 x} \cdot$ 現河床 : $\mathrm{y}=15.88 \cdot 2^{0.0123 x}$ で, 収れん後の MwII 面の值を Ms 面や MwI 面の連続とみなせば, Ms 面 : $\mathrm{y}=20.82 \cdot 2^{0.030 x}$, MwI 面 : $\mathrm{y}=18.28 \cdot 2^{0.073 x}$ となる。こ のことは氷期には上流から下流への粒径の減少率が後水期 に比べ小さいことを示している。ここで段丘縦断面を作製 してみると, 氷期の段丘の縦断面は直線的であり, 後水期 のそれは曲率が大きい。以上から氷期の河川は, 後水期に 比べ直線的な縦断面を持ち，粒径を減少させないような営 力を持っていたことが考えられる。

\section{4. 岩手県玉山村岩洞湖小石川遺跡の石器文化と遺跡立 地}

菊池 強一・阿部 竹彦・武田 良夫 沢口 篤広・岩洞湖小石川遺跡調査団

岩洞湖小石川遺跡は，岩手県玉山村字外山 57-24 にある 後期旧石器時代の開発遺跡である。遺跡は, 1976 年 9 月, 武田良夫によって発見され, 1980 年 8 月 7 日〜 12 日の期間 に玉山村教育委員が緊急発掘調查を実施した。その結果, 北上山地では初めて層位の確実な旧石器時代の遺跡とな り, 石器製作跡の特色を示す出土状況が確認されたので遺 跡立地之あわせて報告する。

遺跡は, 海拔高度 $710 \mathrm{~m}$ に位置し, 小石川の現河床面か らの比高は $20 \mathrm{~m}$, 舌状にはりだした山ろくかんしゃ面に位 置している。

遺跡の層序は, 上位から順に第 I 層一第 VI 層に細分さ れ, 主要遺物包含層は, 第 II 層下部である。

第 I 篔暗褐色〜黒褐色腐植土層。層厚 $50 \mathrm{~cm} \sim 55 \mathrm{~cm}$ 。 三層に細分され下層には, 繩文時代前期に降下した安家火 山灰を狭在する。

第 II 層 暗黄褐色軽石層。層厚 $50 \mathrm{~cm} \sim 65 \mathrm{~cm}$ 。岩相から 
三層に細分され中川他 (1963) の分火山乍層に対比される。 特に上部層は柳沢浮石層, 中部層住小岩井浮石層であり井 上 (1978) による $C^{14}$ 年代は $13,470 \pm 300(\mathrm{Gak}-6465)$ であ る。下部層はクリーム色のパミスを多量に含み遺跡の北に 追跡が可能である。

第 III 層 黄褐色粘土層。層厚 $70 \mathrm{~cm}$ 。下部には生出黑色 火山灰を含み橴民少山乍層に対比される。

第 IV 層 黄褐色砂質角磁層。層厚 $30 \mathrm{~cm}$ 。

第 $\mathrm{V}$ 層 黄褐色粘土層。層厚 $50 \mathrm{~cm}$ 。

第 VI 層 赤褐色角碩層。層厚 $200 \mathrm{~cm}$ 。

第 III 層上面を生活面とする遺物は, ポイント (3 点), 剝 片 (26 点), 屑片 (77 点), 石核 (4 点), 台石 (1 点), 八 ンマーストン (2 点) 等 300 点余で, 石器類の岩質は, 頁岩, 黒よう石, 硅岩がみとめられる。遺物の平面的な分布は, $12 \mathrm{~m} \times 10 \mathrm{~m}$ の円形の範囲に扣さまり，剥片類の接合関係 等から石器製作跡を示すものである。

石器製作技術には, 石刃技法法の流れが読みとれ, 石器 の組成とあわせて判断すると後期旧石器時代最終末を示す 文化と考学られる。

\section{5. 霞ヶ浦岸蓮田地域における戦前の土地改良とその今 日的意義}

田野宏

本報告の目的は，筆者が今春報告を行なった，霞ケ浦岸 土浦市出島村付近の蓮根栽培（地理予 18）の例から, 全国 一の蓮根集団産地である土浦市田村地区を取り上げ，当地 区に機能する耕地条件を戦前, 戦後を通じて比較すること にある。霞ヶ浦岸の沖積地は, 標高約 $5 \mathrm{~m}$ 以下の緩斜面低 地よりなり, 標高 $2 \mathrm{~m}$ 前後を境に, 沖積高位面と沖積低位 面に区分出来る。前者は半湿田, 後者は, 湿田としての耕 地条件を有するが，田村地区は全耕地に占める沖積低位面 の割合が，他の沿岸地域に比べて大きい。従って土地改良 以前は, 湖水位上昇の際に大部分の耕地が冠水し, 収穫皆 無の状態に陥ることしばしばであった。このため, 耕地整 理法に基づく土地改良が他の沿岸地域に先駆けて大正 9 年 に施行され，堤塘敷設・揚排水機の据付，一区画 $10 \mathrm{a}$ の区 画形状整備等が行なわれることで作付は安定した。しかし， 災害を克服し収穫の安定を図ることに重点の置かれた当時 の土地改良は, 戦後の高度経済成長期に打的る乾田化促進 による省力農業に比べて, 湿田が残存する点で, 若干見劣 りのする優地条件を呈することになる。そうした中で当地 区は, 昭和 30 年前後から, 沖積低位面上の優地に米にか わって蓮根が栽培され始め, 更には昭和 45 年に始まる減反 政策によって，半湿田土壤である沖積高位面にまで蓮根栽 培地が应大寸る。その集団地としての規模は全国一のもの であり, 産地化の要因は稲作を上回る家族労働報酬・転作 桨励金の付与，その他，社会的条件をあげることが出来る。
しかし加えて, 湿田残存のままの区画整理化された耕地が， 土地生産性, 労働生産性をあげる点において, 他の蓮根栽 培地に比べて格段の有利性をもたらしていることを見逃す ことが出来ない。戦前に行なわれた耕地整理事業は, 今日 に比べ十分な暗渠排水施設を導入するものではなかったた め, 戦後その耕地条件の価値は減退した。しかし米以外の 作物を求める今日の時代に打いて, 戦前期の土地改良は, 湿田を好む蓮根栽培に対して結果的に, 理想的な耕地条件 をつくり出したものといえる。

\section{6. 奥州信夫郡福島村の御陣屋敷考}

（福島城々下町の研究その 1)

$$
\text { 安田初雄 }
$$

1973(延宝 1) 年の国領半兵衛検地で除地扱いをうけで御 陣屋敷, 御城米舟積場, 寄蔵敷, 御手代屋敷, 籠屋敷, 御 兓など, 1869 (明治 2) 年の福島村差出帳にも「御城附前前 より除地」と記載されているが，「何分相分り不申」と，村 役人にもその大部分の所在がわからなかった。陣屋敷，手 代屋敷は 1664 （寛文 4）年上杉領中上地になった信達が， 幕領として代官支配下に入ったとき，陣屋などの敷地と なった地所である。

（1）これらはみな福島村地区の城附立地でする。その内 舟積場は福島城下絵図に「御城米舟役所」とあり, 寄蔵は その近くの福島河岸中央にあり，後に郷蔵となって，村役 人も知っていた。この城下の絵図に廔々シンャシキの注記 があるのは, 牢即ち籠の敷地である。その両側に厩があっ た（証拠は幾つもある。）

（2）陣屋敷は北町に陣屋口の様が残されていてまどわさ れたが，その北側は明治初年まで腰浜村地内であったこと は多くの史料が明示する故, 福島査地内の城附立地ではな い。但し一時陣屋敷があったか子知れない。しかしそれは 国領検地の陣屋敷ではない。

（3）巡見使案内の手鑑や本多入部時の旧記では，福島城 跡内に陣屋があった上読める記事がある。後の城内で所在 不明となったか。

（4）検地屏風の福島城跡は, 国領検地の水帳記載の畑地 とは異なり，建物があるのは除地となった屋敷の所在を立 証し，中央の大きな建物は陣屋とみられる。

（5）板倉時代の御殿附近は上杉時代から土塁・堀・阿武 隈川にかこまれた要害地で, その面積が陣屋敷の 4320 坪に 近似している。ここなら大手先の外陣屋の地名と対になる。

(6) その東側の本丸とともに，その輪郭は二の内外側の それと不協和で，その他の事実も考光合わせると，この地 区がもとの大仏城または杉妻城（館）の所在地とみられる。 


\section{7. エネルギー定住圈と浜通り地域の開発}

$$
\text { 今 野 修 平 }
$$

福島県浜通り地域は, 南端のいわき市を除くと, 都市化・ 工業化の進展した高度経済成長期, 人口流出を続け，いわ ばとり残された地域となっていた。昭和 40 年代後半に至 り, 漸やく人口減少に歯止めがかかる傾向がみられるよう になってきたものの，依然として二次，三次産業の水準は 低く，住民の生活水準も低い脆弱な体質を示している。

このような浜通り地域も, 仙台市の影響が強いが, 中心 都市の地歩を確立しつつある原町を中心とする北部の相馬 地方と, 中心都市のない双葉地方で，やや様相を異にして いる。しかし工業化の進展や産業構造の変革に, 具体的目 途はなく，高速交通体系の導入も計画がないまま，地域開 発の課題を有したまま，未来への展望が持てないでいる。

この地域に昭和 46 年運開した福島第 1 原子力発電所 (大 熊・双葉）を皮切りに，57 年運開予定の同第 2 （樽葉・富 岡), 62 年運開予定の浪江小高原子力発電所, 55 年運開予 定の広野火力, 60 年運開予定の原町火力と電源地帯化が急 速に進展してきた。

この効果は全域に及ぶ状態ではないが，狭域的には市町 村財政の強化, 商業活動の活発化, 流入人口の増大, 雇傭 増等で顕著にみられるようになっている。今後電源開発が 進展するに従い, 立地点に拈ける開発効果は, 既にその効 果を顕在化している大熊町と同様の期待が持たれよう。し かしながら本地域の脆弱な体質は, 電源開発による開発効 果を拡大再生産して二次効果をあげ得る状況ではなく，さ らに政策的手立ても立遅れて, 開発効果の地域内循環が不 十分なををと思料される。

こうした見解から，開発されるエネルギ一基地と核にし た地域の総合的居住環境の整備を図るといら地域開発への 脱皮が必要でありこれを支える高速交通体系の整備等の基 艋強化が平行して行なわれねばならない。

\section{8. ベルギーの工業化}

一一戦後を中心に—— 和田 明子

ベルギーの戦後の工業化について, 本報告は地域開発に 視点を扣いて究明したい。それはベルギー地域開発研究が, 戦後のベルギー諸地域の経済構造を明らかにする主要な鍵 であるためである。

ベルギー資本主義発展をになった石炭産地ワロン地方 は, エネルギー革命により, 石炭の合理化・近代化をおこ ない, それにともなって莫大な失業者を生じた。一方, 農 業地域であり, 綫維産業地域でもあるフランドル地方は, $\mathrm{EEC}$ 成立以後に, 農業の近代化をせまられ, 繊維産業も構 造不況業種として, その構造改善のための近代化・合理化
により，多くの失業者を生じた。

局地的な失業問題を解消し, 均衝ある所得をあげる地域 開発法（1959 年 7 月，1966 年 7 月，1970年 12 月法）のも とに, ベルギー政府は, 強力な不況地域の産業構造の転換 を企てた。

ワロン地方の工業中心地, ボリナージュ・サントルには, 国庫補助による工業団地が形成され, 石炭産業に代って, 金属, 機械器具, ガラス・薬品などの化学工業が導入され た。

またフランドル地方も,アントワープ・ゲントを中心に， 石油化学, 鉄鋼, 機械工業が多数創設され, 地域の産業構 造が大きく変容した。とくにフランドル地方には, 地域開 発法の誘導にもとづく,アメりカ企業をはじめとする EEC 内の多国籍企業が集中立地した。

この結果, ベルギーの戦後の地域開発は, 国内に地域的 不均等発展をもたらした。従来の国内低開発地域であった フランドル地方は, 急速に近代的な重化学工業基地に変貌 し，かつての先進地域ワロン地方との間に，地域格差が拡 大しつつある。

\section{9. 明治中期における秋田市の祭祀圏}

$$
\text { 益子清 孝 }
$$

本報告は明治中期（明治 20 年代から明治 40 年の神社合 祀以前）に括ける秋田市の祭祀圏から都市の地域構造を明 らかにすることを目的とした。対象地域は明治 22 年におけ る行政区域に限定し，祭祀圈は氏子・崇敬者集団をもとに 検討した。研究方法は「総合郷土研究」(秋田県)，「鉱山の 宗教」（斉藤氏）などの方法を参考にして論を進めた。調査 方法は現地調査を行ない, 文献・記録及び聞き取り調査に よった。結果として,

1. 秋田市の祭祀圏は旭川以東の八幡神社, 旭川以西の 日吉八幡神社，川屑・川口・楢山地区の三森神社の三県社 祭祀圈で構成されている。

2. 県社祭祀圏と村社・無格社祭祀圏とは重合的な関係 になっている。

3. 無格社祭祀圏は一町一社の形態を基礎としている。

4. 秋田市の神社信仰は藩政期にその基礎が確立され, 城下町としての都市構造と密接な関連をもち，社会的結合 の核となっていた。

5. 旭川以東の内町は府城の鎮守・八幡神社の単一信仰 地域として，旭川以東の外町及び下級武士階級の居住地で あった楢山地区は職能分化にともなら職業神や町内鎮守神 などの多様な社京地域として大別でさる。

6. 外町にあっては稲荷信仰が支配的で，之くに旭川・ 太平川・雄物川の合流地域に集積されている。これは藩政 期における佐竹氏の稲荷信仰と外町の商工業者の守護神之 流行神としての機能とが一体となって浸透した。 
7. 近年, 聖なる空間としての神社は集会所・公民館・ 遊園地などに利用され, 地域コミュニティの場としての機 能をもつよらになった。また, 駐車場に利用されたり, ビ ルの屋上に祭祀されるなど機能的に変容している。

\section{0. 冬季における表日本の降水分布に対する共軸相関法 の応用}

田坂 郁夫・設楽寛

スプリーンによって示された「共軸相関法」は既存のい くつかの観測所の降水量とその観測所周辺の地形条件之の 関係を図上で求め，その関係に基づ任意地点の降水量を 地形条件から推定する方法である。観測所の少ない地域の 降水分布を求めるには有効とされ，これまでにもいくつか の地域で適用されている。今回，仙台市の水瓶である名取 川・広瀬川流域に対し，この方法を適用し降水分布を求め た。

暖候期に関しては，従来用いられてきた地形要素，すな わち高度, 起伏度, 谷方向, 露出度などを指標とし, 一応 の結果が得られた。しかし, 寒候期については従来通りの 指標，万法では良い結果は得られなかった。

従来用いられてきた上述の指標は, 地域の上昇気流の強 さ，流入する水蒸気量などと関係する。すなわち，対象之 する地域の地形自身がぞの程度の降水量をもたらすかを考 えている。しかし, 当地域の寒候期の降水の多くは北西季 節風に起因しているため, この地域の地形そのものとは関 係していない。当地域の降水は脊梁山脈の風上地域にその 原因をもつ降水 (降雪) が，いかに運ばれるか，その運ば れ易さにかかっている。

そこで, これらを表わす指標として, 脊梁山脈からの距 離・山脈の高度（峠, 尾根での吹き抜け，吹さ越しに関係 するものとして採用した）ならびに風上，山形盆地の降水 分布の特徴，すなわら北から南へ漸減する特性を示す指標 を新たに加え, 用いる順序も変えた。その結果は一応満足 されるものであった。

共軸相関法には用いる際の地形要素の採り方なども問題 こして残されているが，今回のことは対象地域並びに周辺 の気候特性を考慮し，指標に用いることにより，よりよい 結果の得られることを示しているといえる。

\section{1. 土木工事による流況の変化について}

（馬見ケ崎川を例に）

$$
\text { 加藤 武雄・会田 德旺 }
$$

馬見ケ崎川水系については加藤が 1958 年より水文調査 を開始し，すでに二，三の報文を公けにしている。しかし， その後, 本川上流部の蔵王ダム構築, 滑川上流での笹谷隧 道掘削等，土木工事がなされている。このような以前と異
なる流況と流域の状況下で，馬見ケ崎川水系の水質がどう 変化したか把握するために 1979 年 7 月〜 1980 年 7 月の 1 水年間水質調查を実施し, 以前の資料と比較検討を試みた。

1. 年平均でアニオン, カチオンの当量濃度の大小関係 を比べると，滑川橋と坊原の両観測点とも，1959年代には $\mathrm{Ca}^{2+}>\mathrm{Na}^{+}>\mathrm{Mg}^{2+}$, であったのに1980年代には $\mathrm{Ca}^{2+}>$ $\mathrm{Mg}^{2+} \fallingdotseq \mathrm{Na}^{+}, \mathrm{SO}_{4}^{2-} \fallingdotseq \mathrm{HCO}_{3}^{-}>\mathrm{Cl}^{-}$となっている。1959 年代 の滑川では $\mathrm{HCO}_{3}^{-}>\mathrm{Cl}^{-}>\mathrm{SO}_{4}^{2-}$, 坊原で $\mathrm{SO}_{4}^{2-}>\mathrm{HCO}_{3}^{-}>$ $\mathrm{Cl}^{-}$であるから, 滑川水系の水質変化が大きく, $\mathrm{HCO}_{3}^{-}$型よ り $\mathrm{SO}_{4}^{2-}-\mathrm{HCO}_{3}^{-}$型へ転じていることになる。笹谷㯌道の 湧水の影響である。

2. 平均值で濃度を比べると, 滑川, 坊原とも $\mathrm{pH} 4.3$ $\mathrm{Bx}, \mathrm{Cl}^{-}$濃度, $\mathrm{COD}$ が値を増し, $\mathrm{DO}$ は減少するなど水質污 濁の進行がわかる。

3. $\mathrm{SO}_{4}^{2-}$ 濃度は, 坊原に扣いては両水年に変化はない が，滑川では，1980年に増加するに至っただけでなく，坊 原を超している。な招 $\mathrm{SiO}_{2}$ 濃度は 1980 年の坊原で激減し ている。前者は笹谷隧道湧水の影響で, 後者は蔵王ダムに よる浮流物質の沈殿効果によると考えられる。このような 水質の変化以滑川橋での流送式 $\mathrm{Qd}=\mathrm{aQ}^{n}$ の上にも現れ, $\mathrm{SiO}_{2}$ を除きaの值が高まっている。また，滑川に打ける $\mathrm{Ca}^{2+}, \mathrm{SO}_{4}^{2-}, \mathrm{Cl}^{-}$の年間流送量ならびに $\mathrm{COD}$ 負荷量は 1959 年に比べ 1980 年にはそれぞれ 3 倍, 5.5 倍, 3 倍, 2 倍 にも及んでいる。水質污溞の進行や土木工事の影響である。

4. 滑川での $\mathrm{Ca}^{2+}$ 濃度や $\mathrm{SO}_{4}^{2-}$ 濃度の増加は関沢から 始まるが，それより上流部の水質は良好である。笹谷㯌道 の湧水 $\left(\mathrm{CaSO}_{4}\right.$ を主成分とし， $\mathrm{pH} 7.5$ である) が関沢の上 流で流入する事による。

\section{2. 空間的地形構造におけるスケールの問題について} 米地文夫

地表空間を地形がどのように占有しているかる把える方 法としては，地形分類にもとづく地形区分によるものと演 者の提唱する空間的地形構造（地形間構造）の把握による ものとの 2 つがある。

後者の空間的地形構造とは, これまで構造地形などと用 いられてきたテクトニックなものや，構造段丘などと呼ば れる場合のような組織地形的なものなどとは異なる。すな わち，地質構造ないしは内部構造ではなく，地表空間の構 造であり，見方をかえれば，物質構造ではなく，事象構造 なのである。

この空間的地形構造には, Sender-Receiver (S-R) 構造, Actor-Reactor (A-RA) 構造, Independent (I) 構造の 3 パターンがあり, 前 2 者の複合した構造も加えれば, 4 つ になる。

地形分類にもとづく地形区分の場合は，地形のスケール により，属する地形単位の質も異なる。例之ば，中地形以 
上の場合は山地，平野，盆地など全体性をもつまとまった 地形であるのに対し，小地形はその一部を構成する段丘， 扇状地などの地形単位であり, 微地形はさらにその部分的 単位，段丘崖，段丘面などである。

これに対し, 空間的地形構造は次のような特性を有する。 (1)：スケールを異にしても，それぞれのレベルに拈いて， S-R, A-RA，I, 执よび複合構造, という4 パターンがそれ ぞれみられる。(2)：しかし，同一地点でもスケールば異な る場合には，その属する構造のパターン，拈よびパターン の中の役割は同じであるとは限らず，むしろ変わることが 多い。

以上のことを，5万分の一地形図「新庄」図葉地域を中心 に，同「酒田」図葉地域や，ネパール，カトマンドウ盆地 の例などを加えて，具体的に検討した結果について報告す る。

\section{3. 空間エントロピーの地域比較への応用}

\section{氷見山 幸 夫}

Shannonのエントロピー表現に基き, 空間エントロピー (spatial entropy) としての meal cell entropy と area entropyを下のように定義した。

$$
\begin{aligned}
& \mathrm{H}_{\text {mean }}=\frac{1}{\mathrm{~N}} \sum_{l}^{N} \log n_{l} \\
& \mathrm{H}_{\text {area }}=-\sum_{i}^{M} P_{i} \log p_{i}
\end{aligned}
$$

ただし, $N$ (地域内の小区域の数), $n_{l}$ ( $l$ 番目の小区域内に 見出される要素の数, $M$ (地域内の小区域の種類の数, $p_{i}(i$ 番目の種類の小区域の数の, 全小区域数に対する割合) で ある。これらのエントロピーは, grid system で等しく分割 された地域についての情報を, おのおのの unit cell 内での 特定の要素の有無で記述する場合に対して適用された。具 体的には, 場所のもつ意味をNull（使用されていない場 所), Domestic (住むための場所), Livelihood (仕事のた めの場所), Congregative (Domestic, Livelihood 以外の目 的で使用される場所) の 4 ケの要素で解釈し，その抒の拉 のの要素の有無を調査地域内の各 unit cell について調べ た。調査地域は日本とイギリスの 31 の地域で, 一地域の広 さは $50 \mathrm{~m} \times 50 \mathrm{~m}$ の unit cell 100 ケからなる $500 \mathrm{~m} \times 500$ $\mathrm{m}$ を標準とした。

定義から明らかなように, mean cell entropy は cell 内 での多様度の尺度であり, area entropy は地域全体での cell の多様度の尺度である。

調查地域の比較の結果, 以下の点が明らかとなった。

1. 日本の都市の中心部は mean cell entropy が高く area entropy が低い。即ち cell のレベルでの多様度は大で あるが，地域を通じての変化は少ない。

2.イギリスの都市の中心部は area entropy が日本の
都市よりかなり高く, mean cell entropy も同程度である。 即ち cell のレベルでの多様度が大であると同時に，地域を 通じての変化も大きい。

3. 農村部では両エントロピーとも低いことが多い。即 ち cell のレベルでも地域のレベルでも多様度は低い。

\section{4. 韓国における鉄道貨物流動の地域構造}

韓柱 成

地域間相互の関連を考察するために, 韓国の鉄道貨物流 動をとりあげ, 流動パターンを明らかにし, 併せて, 交通 地域を設定しその特徵を明確にすることを目的とする。

このため発送貨物の流動パターンは Q-モード, 到着貨物 の流動パターンはR-モードの因子分析を行なった。をた， 交通地域の設定は群平均法によるクラスタ一分析を行なっ た。な技，各発送及び到着ゾーンの性格は muftiple linkage analysisで分析した。本研究で使用した資料は鉄道庁が発 行した 1977 年の 56 ゾーン間の貨物発着輸送量である。

結果をまとめると次のようになる。

(1) 56 ゾーンのゾーン間トリップ量によって 10 の貨物 流動パターンの存在が確かめられた。長距離交通手段であ ることと貨物品目の性格のため, その貨物流動パターンは, 明瞭とはいえないが，全国的流動を基礎とし，その上に地 万的, 局地的流動がみられるという二重構造が現われてい る。9つの貨物流動パターンは複核構造を, 残り 1 つの貨物 流動パターンは単核構造を示している。

（2）貨物流動パターンにより交通地域を設定した結果,

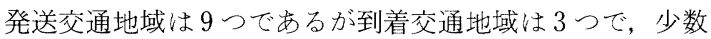
地域への集積が強く現われている。

（3）各交通地域の発送中心度, 到着中心度によると, 発 送交通地域の強さ中蔚山, 古汗, 鉄岩の順であり, また, 到着交通地域の場合，その強さはンウル，釜山の順序であ る。各交通地域はそれぞれ独自の発送圈, 到着圏を持って いる。

（4）鉄道貨物流動による交通地域は，発送交通地域が地 下資源の産地及び重化学工業の発達地であることにより, また, 到着交通地域は消費地人口と工業の発達によって形 成されたと考えられるので，鉄道貨物流動は地下資源，工 業，人口の相互作用により決定されると考光られる。

\section{5、都市と卸売業の集積}

\section{桑 島 勝 雄}

卸売業といらきわめて複雑多岐な都市の経済活動に扔い て，多少なりとも地域現象として把握できる諸事象につい て，分析し整理して，秩序だててみたいと思い，末た，そ のことから都市の性格の側面をも考察してみたいと考光， 今回は特に, 都市にお汀る卸売業従業者の集積態様を中心 として種々の分析を試みたのである。 
その結果として，次のことが指摘される。

(1) 卸売業の集積地域

(1) 3 大都市圈に抢牧る大集積地域の形成，しか子，東 京・大阪・名古屋の 3 大都市への集中的集積が著しい。(2) 1 次的分散的集積地域として広域中心都市の札幌・仙台・ 広島・福岡の 4 都市执よび京都・横浜・神戸の 3 大都市。 (3) 2 次的分散集積地域として, 県庁所在地級都市和よび県 内主要都市, などが集積卓越地域として挙げられる。

（2）集積地域の階層性（数量的段階性）

卸売業従業者数および売上高を指標としてみた場合，各 都市間に执いて量的な格差が著しく, 次のような階層のグ ループに区分することが可能である。第 1 階層として東
京・大阪・名古屋の国家中心都市，第 2 階層として 4 広域 中心都市括よび京都・横浜・神戸の 3 大都市，第 3 階層と して，新潟・北九州・高松・金沢の準広域中心都市拉よび 県都級都市，第 4 階層として，その他県内の主要中心都市 である。

（3）卸壳機能の地域的分化と階層性

卸売流通拠点としての都市の配置と階層をみると, 1 つ は, 総合的拠点都市としての機能的地域分化による階層的 な配置構成であり，も51つは，単一的拠点都市としての 配置構成がみられる。さらに, 前記 2 者を併合した都市が, 両者の間に存在するが, これらは, 総合的拠点都市の系列 に属するものと考えられよう。

\section{0 年度秋季学術大会巡検報告}

「福島県浜通り中部・北部の地域開発」の巡検は, 11 月 3 日（月）文化の日に，25名の参加者を得て実施された。巡 検地域は，中世以降相馬氏約 550 年の支配地でもあるので 副題として，相馬藩の故地を往く，を揭げた。

8 時 30 分, 1900 年代初期に半谷清寺によって開発された 洪積台地夜の森をでて, 原子力発電関係の事務所・宿舎を 久て陸前浜街道の小宿熊町を通り, 相馬藩南境防塁群の あった熊川を渡ると, 原発の町大熊に入る。電源三法によ る現代の地域開発状況をみて, 東京電力・福島第一原子力 発電所で, 建設の地域効果などを聞く。浜通りは, 海岸段 丘が海に迫る地形的条件から，わが国でも有数の原子力発 電所地域に変容しつつあるが，最も早いのがここである。 さらに丘陵地の交互する浜通り海岸低地を北上する，その 沖積地の低地には必ず小中心地が存在する特色がある。双 葉・浪江などもそれで，前者は中世標葉氏の城址があり， 浪江も同じ標葉氏に関係があった。浪江は双葉郡北部から 阿武郎山地にかけての中心的在方町で, 成立根拠権現堂の 旧宿駅をへて，旧陸前浜街道に入り，井田川浦干拓地を遠 望して，鎌倉期の磨崖仏大悲山薬師堂石仏（国实跡）を拝 観し，丘陵の南斜面の立地を按ずる。さらに小高城の南小 高町をへて相馬藩の菩提所同慶寺にいたり藩公の墓所に参 る。再び旧街道を進むが，このあたりには電柱が路傍にな いし，相馬野馬追の小高郷武者の通路でもあり，昔の旅情 を感じさせる。原町市太田で別所の太田神社に詣で相馬氏 発祥の地をみて新国道にでて昼食をとる。午後は, 原町市 南部の 10 月 8 日開通の東京電力寄付による市道陣ケ崎・ 北原線を通り同市南西部の地域開発をみて, 雲隹が原につ く。ここは, かつて相馬藩の大放牧地の一角を占め, 7 月下 旬に行われる国の無形文化財である相馬野馬追祭の華, 神 旗争奪戦の祭場である実感が湧いてくる。この原町は, 1898 年現常磐線の開通時に機関庫が扔かれたことから都市化が
進展し, 1954 年に市制, 1973 年には相馬市にあった国, 県 の出先機関も移動するなどにより市街地も次第に拡大して きた事情をみた。さらに旧街道を北上し, 徒歩交通の往時 を偲びながらも沿道に多くの溜池をみる。このあたりは, 天明, 天保の凶作期後二宮尊德の復興策を導入した相馬藩 の農村振興策である二宮仕法の展開された地域であること を理解して鹿島町にいたる。ここは, 古代の遺跡が多く, いわ壮古代に開発がなされたところとしてとらえる。道路 すぐ近くに円墳がみられるのもここならではの景観であ る。鹿島町から新国道に出て, 相馬民族館・百尺観音・レ ストランなどの道路依存産業をみながら相馬氏居城の中村 城につき，平山城の城内之相馬・中村両神社にいたる。六 万石の石高で国替もなく存続した相馬氏の城下は原町に都 市的勢力を奪われ静かであったが，区画整理による住宅地 の川沼や相馬港の建設など徐々ではあるが新しい動きが始 まっていた。その城下町の一角田町で, 1626 年に藩命によ

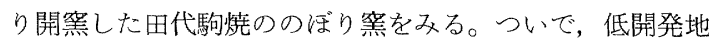
域工業開発の眼玉である相馬港の建設をみ，はるかに金華 山をのぞみ，松川浦県立自然公国の松川浦と松川浦漁港を みて八沢浦干拓地に向い1906１945 年の干拓をとらえた。 さらに海老沢でマルハシャリンバイの北限をみて，原町駅 に向って巡検は終った。

この巡検では，(1) 相馬氏 550 年の故地であること。(2) 二宮仕法の果した役割が大であったこと。(3) 民間人によ る干拓と国の助成。(4) 第 1 次産業中心の開発が 1945 年ま で続いたこと。(5) 開発の方向としては, 南から北, 西から 東へ(浜街道・鉄道・新国道の順) 進んだこと。(6) 低開発 地域工業開発地区・農村地域工業導入地区の指定地域であ ること。(7) 浄土宗徒の多いことと二宮仕法の影響が大で あることなどの総括がなされるであろう。（原田 榮） 